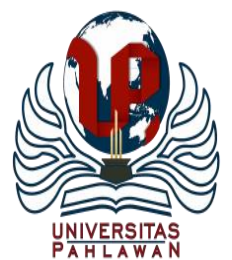

Edukatif : Jurnal Ilmu Pendidikan Volume 3 Nomor 1 Tahun 2021 Halm 44 - 57 EDUKATIF: JURNAL ILMU PENDIDIKAN

Research \& Learning in Education

https://edukatif.org/index.php/edukatif/index

\title{
Pengembangan Kurikulum 2013 dalam Meningkatkan Pendidikan Karakter di Sekolah Dasar
}

\author{
Annisa Nurhidayati Mu'arif ${ }^{1 凶}$, Farahdila Damayanti ${ }^{2}$, Retno Akmalia ${ }^{3}$, Tita Arsfenti ${ }^{4}$, Darmadi $^{5}$ \\ Fakultas Keguruan dan Ilmu Pendidikan Universitas PGRI Madiun, Indonesia ${ }^{1,2,3,4,5}$ \\ E-mail : annisamuarif@gmail.com ${ }^{1} \underline{\text { mymayasmp@gmail.com }}^{2} \underline{\text { retnoakmalia@gmail.com }}^{3}$ \\ titaarsfenti450@gmail.com ${ }^{4}$
}

\begin{abstract}
Abstrak
Penelitian ini bertujuan untuk menganalisis proses pembelajaran dalam jaringan (daring), faktor-faktor pendukung serta faktor-faktor penghambat guru dalam melaksanakan pembelajaran daring di masa pandemi Covid-19. Hasil penelitian menunjukkan bahwa guru melaksanakan kebijakan pemerintah melalui pembelajaran daring. Berbagai faltform digunakan dalam pembelajaran daring. Berbagai respon positif disampaikan peserta didik terkait pembelajaran daring. Namun pelaksanaan pembelajaran pada masa pandemic Covid-19 ini memiliki tantangan/kendala, baik dari aspek sumber daya manusia, sarana-prasarana, dan teknis implementasi. Sebagai rekomendasi ke depan, dibutuhkan kemitraan publik dan keterlibatan banyak pihak secara berkelanjutan. Kompetensi dan keterampilan guru harus terus diperkaya, didukung oleh kebijakan sekolah yang mendorong guru terus belajar. Pembelajaran daring yang dilakukan untuk anak usia sekolah dasar dirasa kurang efektif seperti kurang maksimalnya penyampaian materi , koneksi internet yang kadang mnejadi lamban, gaya belajar yang cenderung visual, dan kurang leluasanya guru dalam mengontrol kegiatan siswa maka dari itu pencapaian belajar peserta didik tentunya harus diperhitungkan, diukur, baik secara materi maupun waktu. Guru tidak boleh sematamata memberikan tugas tetapi harus memperhitungkan secara matang. Guru tidak boleh lupa untuk mengapresiasi capaian peserta didik. Kurikulum yang fleksibel dan siap menghadapi pandemi juga dibutuhkan.
\end{abstract}

Kata Kunci: Pengembangan Kurikulum, Peningkatan Pendidikan Karakter

\section{Abstract}

This study aims to analyze the learning process online, supporting factors and inhibiting factors for teachers in implementing online learning during the Covid-19 pandemic. The results showed that teachers implemented government policies through online learning. Various forms are used in online learning. Various positive responses were conveyed by students regarding online learning. However, the implementation of learning during the Covid19 pandemic has challenges / obstacles, both in terms of human resources, infrastructure, and technical implementation. As a recommendation for the future, public partnerships and involvement of many parties are needed in a sustainable manner. Teacher competencies and skills must be continuously enriched, supported by school policies that encourage teachers to continue learning. Online learning carried out for elementary school age children is deemed ineffective, such as inadequate delivery of material, internet connection which sometimes becomes slow, learning styles that tend to be visual, and teachers lack flexibility in controlling student activities, therefore the learning achievement of students must of course be taken into account, measured, both materially and in time. Teachers should not only give assignments but must take into account carefully. Teachers must not forget to appreciate the achievements of students. A curriculum that is flexible and ready to face a pandemic is also needed.

Keywords: Curriculum Development, Character Education Improvement.

Copyright (c) 2021 Annisa Nurhidayati Mu'arif, Farahdila Damayanti, Retno Akmalia, Tita Arsfenti, Darmadi

$\triangle$ Corresponding author

Email : annisamuarif@gmail.com

DOI: https://doi.org/10.31004/edukatif.v3i1.164

ISSN 2656-8063 (Media Cetak)

ISSN 2656-8071 (Media Online) 


\section{PENDAHULUAN}

\section{Latar Belakang}

Dengan seiring berkembangnya zaman menuntut semua yang ada di dunia mengikuti perkembangannya. Salah satunya di dunia pendidikan seperti semakin berkembangnya kurikulum yang digunakan untuk sekolah. Kurikulum sendiri selalu mengalami perubahan dari masa ke masa sesuai dengan perkembangan ilmu pengetahuan dan tututan dalam masyarakat. Hal ini dapat disebut juga sebagai pengembangan kurikulum. Pengembangan kurikulum bertujuan untuk memperbaiki evaluasi dari kurikulum sebelumnya sehingga kurikulum tersebut dapat menjadi bahan ajar dan acuan yang digunakan untuk mencapai tujuan pendidikan nasional.

Pada saat ini kurikulum yang digunakan adalah kurikulum 2013 yang mana lebih menekankan pendidikan karakter pada pelajar. Dapat dilihat seiring dengan perkembangan zaman karakter anak-anak dan remaja sangat memprihatinkan. Banyak perilaku dari peserta didik mulai tingkat SD-SMA bertentangan dengan nilai-nilai pendidikan karakter contoh nya seperti rendahnya budaya disiplin dan tertib belajar disekolah, meningkatnya jumlah siswa yang bolos dan absen saat jam pelajaran, meningkatnya kelompok komunitas geng motor yang setiap kali 'ugal-ugalan' dijalan-jalan protokol, adanya budaya menyontek hingga plagarisme, meningkatnya tawuran antar pelajar, serta bentuk-bentuk kenakalan remaja lainnya terutama di kota-kota besar, pemerasan, kekerasan (bullying-red), kecenderungan dominasi senior terhadap junior dan berbagai fenomena buruknya karakter pelajar kita. Dengan keadaan seperti ini pendidik karakter perlu diperkuat disetiap lembaga pendidikan mulai dari SD-SMA. Sekolah Dasar merupakan tempat pendidikan dasar dari anak-anak dimana pada tingkat pendidikan ini sangat penting untuk memperoleh pendidikan karakter. Apabila pada tingkat Sekolah Dasar sudah ditekankan pendidikan karakter maka para pelajar akan lebih mudah dan mengingat untuk menerapkan karakter yang baik sampai mereka dewasa nanti. Oleh karena itu pengembangan kurikulum untuk meningkatkan pendidikan karakter di Sekolah Dasar sangat penting untuk segera diterapkan.

\section{Perumusan Masalah}

1. Bagaimana pengembangan kurikulum dalam meningkatkan pelaksanaan pendidikan karakter di SD Kecamatan Taman?

2. Kegiatan apa saja yang terdapat dalam kurikulum untuk mendukung pendidikan karakter di SD Kecamatan Taman?

3. Apa saja faktor pendukung dan penghambat dalam pelaksanaan peningkatan pendidikan karakter melalui pengembangan kurikulum di SD Kecamatan Taman?

\section{Tujuan Penelitian}

1. Mengetahui pengembangan kurikulum dalam peningkatan pendidikan karakter di SD Kecamatan Taman

2. Mengetahui kegiatan yang terdapat dalam kurikulum untuk pendidikan karakter di SD Kecamatan Taman

3. Mengetahui faktor pendukung dan penghambat dalam pelaksanaan peningkatan pendidikan karakter melalui pengembangan kurikulum

\section{Manfaat Penelitian}

1. Membantu mahasiswa mengetahui bagaimana pengembangan kurikulum di SD Kecamatan Taman.

2. Membantu mahasiswa mengetahui bagaimana Pengembangan Kurikulum dalam meningkatkan pendidikan karakter di SD Kecamatan Taman.

\section{Kajian Pustaka}




\section{Pengembangan Kurikulum}

Kurikulum merupakan hal yang pokok dalam dunia pendidikan. Hal-hal yang berhubungan dengan pencapaian tujuan pendidikan dipandang sebagai kurikulum. Kurikulum merangkum semua pengalaman belajar yang disediakan bagi siswa di sekolah. Dalam kurikulum terintegrasi filsafat, nilai-nilai, pengetahuan, dan perbuatan pendidikan. Kurikulum disusun oleh para ahli pendidikan, mereka itu pendidik, pejabat pendidikan, penguasaha serta unsur-unsur masyarakat lainnya. Pengembangan kurikulum adalah sebuah proses yang merencanakan, menghasilkan suatu alat yang lebih baik dengan didasarkan pada hasil penilaian terhadap kurikulum yang telah berlaku, sehingga dapat memberikan kondisi belajar mengajar yang baik. Dengan kata lain, pengembangan kurikulum adalah kegiatan untuk menghasilkan kurikulum baru melalui langkah-langkah penyusunan kurikulum atas dasar hasil penilaian yang dilakukan selama periode waktu tertentu. Pengembangan kurikulum dilakukan karena sifat kurikulum yang dinamis, selalu berubah, menyesuaikan diri dengan kebutuhan mereka yang belajar. Disamping itu, masyarakat dan mereka yang belajar mengalami perubahan maka langkah awal dalam perumusan kurikulum ialah penyelidikan mengenai situasi (situation analysis) yang kita hadapi, termasuk situasi lingkungan belajar dalam artian menyeluruh, situasi peserta didik, dan para calon pengajar yang diharapkan melaksanakan kegiatan.

Dalam pengembangan kurikulum diperlukan dasar-dasar pengembangan. Dasar-dasar pengembangan kurikulum menurut Oemar Hamalik (2012:98) adalah sebagai berikut:

1. Kurikulum disusun untuk mewujudkan system pendidikan nasional.

2. Kurikulum pada semua jenjang pendidikan dikembangkan dengan pendekatan kemampuan.

3. Kurikulum harus sesuai dengan ciri khas satuan pendidikan pada masing-masing jenjang pendidikan.

4. Kurikulum pendidikan dasar, menengah dan tinggi dikembangkan atas dasar standar nasional pendidikan untuk setiap jenis dan jenjang pendidikan.

5. Kurikulum pada semua jenjang pendidikan dikembangkan secara berdiversifikasi, sesuai dengan kebutuhan potensi, dan minat peserta didik dan kebutuhan pihak-pihak yang memerlukan dan berkepentingan

6. Kurikulum dikembangkan dengan memperhatikantuntutan pengembangan daerah dan nasional, keanekaragaman potensi daerah dan lingkungan serta kebutuhan pengembangan iptek dan seni.

7. Kurikulum pada semua jenjang pendidikan dikembangkan secara berdiversifikasi, sesuai dengan tuntutan lingkungan dan budaya setempat.

8. Kurikulum pada semua jenjang penidikan mencakup aspek spiritual keagamaan, inteltualitas.

Selain dasar dasar pengembangan kurikulum dalam pengembangan kurikulum terdapat 4 landasan diantaranya:

1. Landasan filosofis

Filsafat suatu Negara atau pandangan hidup suatu bangsa berisi ide-ide,cita-cita,system nilai yang harus dipertahankandemi kelangsungan hidup bangsa.

Di Indonesia pandangan hidup bangsa adalah PANCASILA, dengan demikian penyelenggaraan pendidikan secara resmi diarahkan untuk membentuk manusia Indonesia yang ber-PANCASILA.

2. Landasan Sosial-Budaya-Agama

Di Indenesia penyusunan dan pengembangan kurikulum sekolah-sekolah mulai dari TK sampai PT perlu mempertimbangkan landasan-landasan social-budaya-agama yang hidup dan berkembang di Indonesia.Dengan dmikian anak setelah tamat dari sekolah yang bersangkutan tidak akan canggung lagi menyesuaikan diri dengan lingkungan social-budaya-agamanya masing-masing.

3. Landasan Ilmu Pengetahuan Teknologi dan Seni 
Ilmu pengetahuan dan teknologi merupakan hasil budi daya manusia sejak dahulu sampai sekarang, yang makin lama makin maju,maka dalam penyusunan pengembangan kurikulum perlu mempertimbangkan landsan ilmu pengetahuan dan teknologi.

4. Landsan kebutuhan manusia

Karena anak akan hidup dalam masyarakat,maka anakpun harus dipersiapkan untuk terjun di masyarakat denga dibekali kemampuan dan ketrampilan yang dibutuhkan masyarakat.

5. Landasan perkembangan masyarakat.

Didalam masyarakat terdapat bemacam-macam lembaga social yang masing-masing memiliki kekuatan untuk tumbuh dan berkembang.Ini semua memberikan pengaruuh dan perludipertimbangkan dalam rangka pembinaan dan pengembangan kurikulum.Sehingga sejalan dengan sifat dinamis dalam masyarakat yang selalu berkembang.

\section{Prinsip prinsip pengembangan kurikulum}

1. Prinsip Relevansi

Yang dimaksud dalam dunia pendidikan adalah adanya kesesuaian antara hasil pendidikan dengan tuntutan kehidupan yangada di masyarakat.

2. Prinsip Kontinuitas

Prinsip ini maksudnya adanya saling hubungan antara saling hubungan antara berbagai tingkat dan jenis program pendidikan,terutama mengenai bahan pelajaran.

3. Prinsip Fleksibilitas

Yang dimaksud fleksibilitas adanya semacam ruang gerak yang memberikan sedikit kebebasan dalam bertindak.

\section{Model-model pengembangan kurikulum}

1) Model pengembangan kurikulum menurut Rogers

Model 1

Menggambarkan bahwa kegiatan pendidikan semata-mata terdiri dari kegiatan memberikan informasi dan ujian dan evaluasi.

Model 2

Merupaknan penyempurnaan dari model 1 dengan menambahkan komponen metode dan organisasi bahan pelajaran.

Model 3

Pengembangan kurikulum model 3 merupakan penyempurnaan dari model 2,dengan menambahkan unsure teknologi pendidikan kedalamnya.

Model 4

Pengembangan kurikulum model 4 ini merupakan penyempurnaan dari model 3 dengan memasukkan unsur tujuan kedalamnya.

2) Model pengembangan kurikulum menurut Zais

Model Administratif

Biasa disebut “garis dan staf".Kegiatan pengembangan kurikulum ini dimulai dari pejabat pendidikan yang berwenang,yang membentuk panitia pengarah yang terdiri dari pengawas pendidikan,kepala sekolah dan staf pengajar inti. 
Model dari bawah

Inisiatif pengembangan kurikulum ini berasal dari bawah yaitu dari para pengajar yang merupakan pelaksana kurikulum sekolah.

3) Model Beauchamp

Keutusan dalam model ini meliputi 5 langkah:

1. Menentukan arena pengembangan kurikulum

2. Memilih kemudian mengikut sertakan para pengembang kurikulum

3. Mengorganisasi dan menentukan prosedur perencanaan kurikulum

4. Menerapkan atau melaksanakan kurikulum secara sistematis

5. Melakukan penilaian kurikulum yang telah dan sedang dilaksanakan

4) Model terbalik Hilda-Taba

Pengembangan kurikulum ini melalui 5 tahap:

1. Menyusun unit-unit kurikulumyang akan di ujicobakan

2. Mengujicobakan

3. Menganalisis dan merevisi hasil ujicoba

4. Menyusun kerangka kerja teoritis

5. Menyusun kurikulum secara menyeluruh dan mendesiminasikan

Pengembangan kurikulum tidak hanya merupakan abstraksi, akan tetapi mempersiapkan berbagai contoh dan alternatif untuk tindakan yang merupakan inspirasi dari beberapa ide dan penyesuaianpenyesuaian lain yang dianggap penting. Menurut Audrey Nicholls dan Howard Nicholls, sebagaimana dipahami oleh Oemar Hamalik, bahwa pengembangan kurikulum adalah perencanaan kesempatankesempatan belajar yang dimaksudkan untuk membawa siswa ke arah perubahan-perubahan yang diinginkan dan menilai sampai di mana perubahan dimaksud telah terjadi pada diri siswa.

Fungsi dasar atau landasan pengembangan kurikulum adalah seperti fondasi sebuah bangunan. Sebuah gedung yang menjulang tinggi berdiri di atas fondasi yang rapuh tentu tidak akan bertahan lama. Oleh sebab itu, sebelum sebuah gedung dibangun, terlebih dahulu dibangun fondasi yang kokoh. Semakin kokoh fondasi sebuah gedung, maka akan semakin kokoh pula gedung tersebut. Fondasi bangunan yang diibaratkan pada uraian di atas adalah dasar atau landasan dalam merancang sebuah kurikulum. Jadi, berkualitas atau tidaknya kurikulum yang dirancang, sangat ditentukan oleh dasar pengembangan kurikulum yang kuat. Seller dan Miller, sebagaimana dikutip oleh Sanjaya, mengemukakan bahwa proses pengembangan kurikulum adalah rangkaian kegiatan yang dilakukan secara terus-menerus.

Ada empat tahap pengembangan kurikulum dilihat dari tingkatannya antara lain:

1. Pengembangan kurikulum pada tingkat nasional.

Pengembangan kurikulum pada tingkat ini membahas pendidikan pada tingkat nasional yang terdiri dari pendidikan formal, informal, dan non formal. Dari tingkatannya dapat dilihat secara vertikal dan horizontal. Secara vertikal, pengembangan kurikulum dilakukan berdasarkan tingkatan pendidikan dari yang terendah sampai ke tinggi. Sedangkan Secara horizontal, pengembangan kurikulum berdasarkan pendidikan yang sederajat, seperti contoh SD, MI, dan program paket A

2. Pengembangan kurikulum pada tingkat institusi 
Pengembangan kurikulum tingkat ini memiliki beberapa kegiatan yang harus dilaksanakan antara lain, merumuskan tujuan yang akan dicapai sekolah, menyusun SKL (standar kompetensi lulusan), dan penetapan isi kurikulum secara keseluruhan. Standar kompetensi lulusan berupa rumusan kompetensi pengetahuan, keterampilan, dan sikap yang harus dicapai oleh siswa setelah mengikuti pembelajaran pada lembaga pendidikan. SKL tersebut dirumuskan sesuai dengan jenis dan tingkatannya. Standar kompetensi lulusan menunjukkan harapan masyarakat, seperti orangtua, penjabat pemerintah dan swasta tentang dunia pendidikan, dunia usaha, dan lain-lain, serta merupakan harapan bagi pendidikan jenjang tinggi atau dunia kerja.

3. Pengembangan kurikulum pada tingkat mata pelajaran

Silabus merupakan bentuk pengembangan kurikulum pada tingkat mata pelajaran. Silabus yang terdiri dari kompetensi inti, kompetensi dasar, materi pokok, kegiatan pembelajaran, indikator pencapaian, bentuk penilaian dan alokasi waktu disusun pada setiap semester.

4. Pengembangan kurikulum pada tingkat pembelajaran di kelas.

Pada tingkat pembelajaran dikelas pengembangan kurikulum dilakukan dalam bentuk susunan RPP ( Rencana Pelaksanaan Pendidikan) yang dirancang oleh masing-masing guru. Perencanaan tersebut juga meliputi sumber belajar yang akan digunakan.

\section{Kurikulum di Masa Pandemi}

1) Pengembangan Materi Pembelajaran di Masa Pandemi

Di masa pandemi guru dapat memilih materi pelajaran esensi untuk menjadi prioritas dalam pembelajaran. Sedangkan materi lain dapat dipelajari siswa secara mandiri. Materi pembelajaran ditemukan dan dikumpulkan serta dikembangkan dari; buku-buku sumber seperti buku siswa, buku pedoman guru, maupun buku atau literatur lain yang berkaitan dengan ruang lingkup yang sesuai dan benar; hal-hal yang berkaitan dengan kehidupan dan/atau berkaitan dengan fenomena sosial yang bersifat kontekstual, misalnya berkaitan dengan pandemi Covid-19 atau hal lain yang sedang terjadi di sekitar siswa.

2) Model dan Metode Pembelajaran di Masa Pandemi

Desain pembelajaran mengunakan pendekatan berbasis ilmiah/saintifik dapat berbentuk model-model pembelajaran, seperti model Pembelajaran Berbasis Penemuan (Discovery learning) model Pembelajaran Berbasis Penelitian (Inquiry learning), Model Pembelajaran Berbasis Proyek (Project Based Learning), Model Pembelajaran Berbasis Masalah (Problem Based Learning), dan model pembelajaran lainnya yang memungkinkan peserta didik belajar secara aktif dan kreatif. Guru dapat memilih metode yang memungkinkan pencapaian tujuan pembelajaran pada kondisi darurat.Guru secara kreatif mengembangkan metode pembelajaran aktif yang disesuaikan dengan karakteristik materi/tema.

\section{3) Media dan Sumber Belajar}

Pada prinsipnya segala benda yang sesuai dapat dijadikan media pembelajaran.Guru diharapkan kreatif dan inovatif untuk memanfaatkan benda tersebut menjadi media agar dapat membantu tercapainya tujuan pembelajaran. Beberapa contoh media pembelajaran sederhana antara lain: Gambar, Peta dan Globe, Grafik, Papan Tulis, Papan Flanel, Display, Poster, Bagan (Chart), dan sebagainya. Pemilihan media disesuaikan dengan materi/tema yang diajarkan dan tagihan sesuai indikator dan tetap mempertimbangkan kondisi kedaruratan. 
4) Perencanaan Pembelajaran di Masa Pandemi

Pada masa pandemi guru tetap harus menyusun rencana pelaksanaan pembelajaran (RPP). Dalam menyusun RPP, guru harus merujuk pada SKL, KI-KD dan dan Indikator Pencapaian yang diturunkan dari KD. Guru dapat membuat pemetaan KD dan memilih materi esensi yang akan di ajarkan kepada peserta didik pada masa pandemi. Dalam setiap menyusun RPP, terdapat 3 (tiga) ranah yang perlu dicapai dan perlu diperhatikan pada setiap akhir pembelajaran, yaitu dimensi sikap, aspek pengetahuan, dan aspek keterampilan. Dimensi sikap mencakup nilai-nilai spiritual sebagai wujud iman dan takwa kepada Allah SWT, mengamalkan akhlak yang terpuji dan menjadi teladan bagi keluarga masyarakat dan bangsa, yaitu sikap peserta didik yang jujur, disipilin, tanggungjawab, peduli, santun, mandiri, dan percaya diri dan berkemauan kuat untuk mengimplementasikan hasil pembelajarannya di tengah kehidupan dirinya dan masyarakatnya dalam rangka mewujudkan kehidupan beragama, bermasyarakat, berbangsa, dan bernegara yang lebih baik.Dimensi pengetahuan yaitu memiliki dan mengembangkan pengetahuan secara konseptual, faktual, prosedural dan metakognitif secara teknis dan spesifik dari tingkat sederhana, kongkrit sampai abstrak, komplek berkenaaan dengan pengembangan ilmu pengetahuan, teknologi, seni dan budaya masyarakat sekitar, lingkungan alam, bangsa, negara dan kawasan regional, nasional maupun internasional. Dimensi keterampilan yaitu memiliki keterampilan berpikir tingkat tinggi dan bertindak: kreatif, produktif, kritis, mandiri, kolaboratif, dan komunikatif serta mampu bersaing di era global dengan kemampuan sikap, pengetahuan dan keterampilan yang dimiliki.Perencanaan pembelajaran dapat menggunakan edaran Menteri Pendidikan Nomor 14 Tahun 2019 tentang penyederhanaan RPP di mana unsur yang ditulis mencakup tujuan pembelajaran, langkah-langkah pembelajaran, dan penilaian.

5) Kegiatan Pembelajaran di Masa Pandemi

Kegiatan di masa pandemi harus memperhatikan berbagai aspek dan regulasi. Salah satu regulasi penting yang harus dijadikan rujukan adalah SKB 4 Menteri (Menteri Pendidikan, Menteri Agama, Menteri Kesehatan, dan Menteri dalam Negeri). Kegiatan pada masa darurat terbagi atas zona di masing-masing daerah. Hanya zona hijau yang dapat melaksanakan pembelajaran tatap muka dengan dua fase yakni fase transisi dan fase new normal. Selain itu harus memperhatikan protokol kesehatan yang berlaku dan memperoleh rekomendasi dari dinas kesehatan. Sedangkan zona merah, kuning, dan oranye tidak dapat melaksanakan pembelajaran tatap muka sehingga pembelajaran dilakukan secara daring. Oleh karena itu, sekolah diharapkan kreatif dalam membuat media untuk kegiatan pembelajaran yang efektif dan efisien.

6) Penilaian Hasil Belajar

Penilaian hasil belajar mengacu pada regulasi/ juknis penilaian hasil belajar dengan penyesuaian masa pandemi. Bentuk penyesuaian sangat kondisional tergantung infrastruktur pendukung masing-masing sekolah/madrasah.

\section{Pendidikan Karakter}

Secara sederhana pendidikan dapat dimaknai sebagai usaha membantu peserta didik mengembangkan seluruh potensinya (hati, pikir, rasa, dan karsa, serta raga) untuk menghadapi masa depan. Pada sisi lain, pendidikan karakter pada dasarnya mencakup pengembangan substansi, proses, dan suasana atau lingkungan yang menggugah, mendorong, dan memudahkan seseorang untuk mengembangkan kebiasaan baik dalam kehidupan sehari-hari. Kebiasaan ini timbul dan berkembang dengan didasari oleh kesadaran, keyakinan, kepekaan, dan sikap orang yang bersangkutan. Dengan demikian, karakter yang ingin dibangun melalui pendidikan karakter bersifat inside-out, dalam arti bahwa perilaku yang terjadi karena dorongan dari dalam, bukan paksaan dari luar (Zubaedi, 2011: 191). Sehingga desain pendidikan karakter meliputi pengembangan 
potensi manusia dalam pengembangan karakter yang baik. Karakter dibentuk oleh beberapa faktor, baik internal maupun eksternal, menurut Aushop (2014: 3) faktor-faktor yang dapat berpengaruh teradap pembentukkan karakter peserta didik diantaranya:

a. Corak nilai yang ditanamkan;

b. Keteladanan sang idola;

c. Pembiasaan;

d. Ganjaran dan hukuman; dan

e. Kebutuhan

Oleh karenanya, maka pendidikan karakter diniscayakan untuk menekankan pada keteladanan, penciptaan lingkungan, dan pembiasaan; melalui berbagai tugas keilmuan dan kegiatan kondusif. Dengan demikian, apa yang dilihat, didengar, dirasakan, dan dikerjakan oleh peserta didik dapat membentuk karakter mereka. Selain menjadikan keteladanan dan pembiasaan sebagai metode pendidikan utama, penciptaan iklim dan budaya, serta lingkungan yang kondusif juga sangat penting, dan turut membentuk karakter peserta didik (Mulyasa, 2013:10). Dalam ruang lingkup lembaga pendidikan (sekolah/ madrasah), Mulyasa (2013: 13-40) menyatakan bahwa kunci sukses pendidikan karakter di sekolah adalah:

a. Pahami hakekat pendidikan karakter;

b. Sosialisasi dengan tepat;

c. Ciptakan lingkungan yang kondusif;

d. Dukung dengan fasilitas dan sumber belajar yang memadai;

e. Tumbuhkan disiplin peserta didik;

f. Pilih pimpinan yang amanah;

g. Wujudkan guru yang dapat digugu dan ditiru; dan

h. Libatkan seluruh warga sekolah.

Pendidikan karakter memiliki fungsi sebagai (Kemendiknas, 2010):

1. Wahana pengembangan, yaitu pengembangan potensi peserta didik untuk menjadi berperilaku yang baik bagi peserta didik yang telah memiliki sikap dan perilaku yang mencerminkan karakter;

2. Wahana perbaikan, yaitu memperkuat kiprah pendidikan nasional untuk lebih bertanggung jawab dalam pengembangan potensi peserta didi yang lebih bermartabat;

3. Wahana penyaring yaitu untuk menyaring budaya-budaya bangsa sendiri dan budaya bangsa lain yang tidak sesuai dengan nilai-nilai karakter.

Ada beberapa prinsip dalam pendidikan karakter yakni

1. manusia adalah makhluk yang dipengaruhi dua aspek, pada dirinya memiliki sumber kebenaran dan pada luar dirinya ada dorongan atau kondisi yang memengaruhi kesadaran.

2. karena menganggap bahwa perilaku yang dibimbing oleh nilai-nilai utama sebagi bukti dari karakter, pendidikan karakter tidak meyakini adanya pemisahan antara roh, jiwa, dan badan. Hadis Rosulullah menyatakan bahwa iman dibangun oleh perasaan serta roh, jiwa dan badan, yaitu melalui perkataan, keyakinan, dan tindakan. Tanpa tindakan semua yang diucapkan dan diyakini bukanlah apa-apa tanpa keyakinan maka tindakan dan perkataan tidak memiliki makna, kemudian tanpa pernyataan dalamperkataan tindakan dan keyakinan tidak akan terhubung. 
3. Pendidikan karakter mengutamakan munculnya kesadaran pribadi peserta didik untuk secara ikhlas mengutamakan karakter positif. Setiap manusia memiliki modal dasar (potensi yang membedakan dirinya dengan orang lain. Aktualisasi dari kesadaran ini dalam dunia pendidikan adalah pemupukan keandalan khusus seseorang yang memungkinkannya memiliki daya tahan dan daya saing dalam perjuangan hidup.

4. Pendidikan karakter mengarahkan peserta didik untuk menjadi manusia ulul albab yang tidak hanya memiliki kesadaran diri, tetapi juga kesadaran untuk terus mengembangkan diri, memperhatikan masalah lingkungan, dan memperbaiki kehidupan sesuai dengan pengetahuan dan karakter yang dimilikinya. Manusia ulul albab adalah manusia yang dapat diandalkan dari segala aspek, baik aspek intelektual, afektif, maupun spiritual.

Di Indonesia ini kita tahu bahwa mencontek telah menjadi budaya lembaga pendidikan kita. Hal ini bukan hanya berkaitan dengan kelemahan individu per individu, melainkan telah membentuk sebuah kultur sekolah yangtidak menghargai kejujuran. Masifnya perilakuketidakjujuran ini telah merambah dalam dirisiswa, pendidik, dan anggota komunitas sekolah.Pembangunan karakter dan pendidikankarakter menjadi suatu keharusan karenapendidikan tidak hanya menjadikan peserta didikmenjadi cerdas, juga mempunyai budi pekerti dansopan santun, sehingga keberadaannya sebagaianggota masyarakat menjadi bermakna baik bagidirinya maupun orang lain. Pembinaan karakter yang termudah dilakukan adalah ketika anak-anak masih duduk di bangku SD. Itulah sebabnya pemerintah memprioritaskan pendidikan karakterdi SD. Bukan berarti pada jenjang pendidikan lain-nya tidak mendapat perhatian namun porsinyasaja yang berbeda (Mendiknas, 2010).

Untuk mendukung keberhasilan pendidikan karakter, perlu dilakukan sosialisasi tentang moral dasar yang perlu dimiliki anak dan remaja untuk mencegah remaja melakukan kejahatan yang dapat merugikan diri remaja itu sendiri maupun orang lain. Melalui pendidikan karakter akan tertanam nilai-nilai karakter yang baik di dalam diri individu. Nilai-nilai karakter yang baik akan menuntun seseorang dalam berperilaku sehari-hari. Pendapat tersebut senada dengan yang disampaikan Wibowo (2012: 36) bahwa pendidikan karakter merupakan proses pendidikan yang menanamkan dan mengembangkan karakter-karakter luhur kepada anak didik, sehingga mereka memiliki karakter luhur, dan menerapkan serta mempraktikan dalam kehidupannya, baik di lingkungan keluarga, warga masyarakat, maupun warga negara.

Pendidikan karakter tidak dapat dilakukan di dalam suatu ruang hampa (vacuum tube) yang bebas nilai karena karakter sangat erat (bounded) dengan kehidupan (Suryadi, 2012: 96). Berdasarkan penjelasan tersebut maka pendidikan karakter di sekolah tidak akan berhasil jika pembelajarannya hanya berupa hafalan secara verbalistik saja. Tidak ada jaminan jika pendidikan karakter itu berdiri sendiri sebagai mata pelajaran, maka akan berhasil dengan baik. Oleh karena itu, pelaksanaan pendidikan karakter di sekolah hendaknya dapat dilakukan dengan mengintegrasikan ke dalam mata pelajaran.

Menurut Rachman (2000), tujuan pendidikan karakter diantaranya adalah sebagai berikut:

1. Mengembangkan potensi afektif peserta didik sebagai manusia dan warga negara yang memiliki nilainilai karakter.

2. Mengembangkan kebiasaan dan perilaku peserta didik yang terpuji dan sejalan dengan nilai-nilai universal dan tradisi budaya dan karakter bangsa.

3. Menanamkan jiwa kepemimpinan dan tanggung jawab peserta didik sebagai generasi penerus bangsa.

4. Mengembangkan kemampuan peserta didik menjadi manusia yang mandiri dan kreatif.

5. Mengembangkan lingkungan kehidupan sekolah sebagai lingkungan belajar yang aman, jujur, penuh kreativitas dan persahabatan, serta dengan rasa kebangsaan yang tinggi dan penuh kekuatan. 
Lickona dan Amirulloh (2015, hlm.14-18) menjelaskan bahwa sistem karakter terdiri tiga ranah yang saling berhubungan dan saling mempengaruhi, yakni:

1) Pengetahuan Moral (Moral Knowledge)

Pengetahuan moral terdiri dari enam komponen yang meliputi:

a. Kesadaran Moral, merupakan kesadaran untuk memperhatikan dan melaksanakan moral yang ada di sekitarnya.

b. Pengetahuan Nilai Moral, kemampuan untuk memahami nilai moral dalam berbagai situasi.

c. Memahami Sudut Pandang Lain, adalah kemampuan untuk menghargai dan merasakan pendapat orang lain.

d. Penalaran Moral, kemampuan untuk memahami, mempertimbangkan dan membedakan makna bermoral.

e. Keberanian Mengambil Keputusan, yaitu kemampuan untuk tidak ragu menentukan pilihan yang tepat saat mengalami dilema moral.

f. Pengenalan Diri (Self Knowledge), mampu mengetahui dan memahami perilaku sendiri serta dapat mengevaluasinya dengan jujur.

2) Perasaan Moral (Moral Feeling)

Perasaan moral terdiri dari enam komponen, yaitu:

a. Mendengarkan Hati Nurani, yaitu perasaan moral naf mendorong seseorang untuk melakukan tindakan sesuai dengan hati nurani dalam sisi kognitif dan sisi emosional. Sepintar-pintarnya manusia, kelebihannya adalah tetap memperhatikan emosi dan tidak buta terhadap sesuatu yang objektif jika dibandingkan dengan kecerdasan buatan.

b. Harga Diri (self esteem), yakni memiliki kesadaran untuk menjaga harkat dan martabat berdasarkan nilai yang luhur.

c. Empati, memiliki kepekaan (mampu turut merasakan) penderitaan orang lain.

d. Cinta Kebaikan, kemampuan untuk merasa suka dan senang ketika melakukan kebaikan.

e. Kontrol Diri, kemampuan untuk mengendalikan emosi berlebih, baik saat marah ataupun terlalu senang (euforia).

f. Rendah Hati (humility), berarti tidak merasakan rasa keunggulan yang berlebih, dapat tetap terbuka terhadap perbaikan kesalahan dan mengatasi rasa sombong namun tetap percaya diri.

3) Tindakan Moral

Tindakan moral terdiri menjadi tiga komponen utama, yakni:

a. Kompetensi (competence), merupakan kemampuan untuk mengubah perasaan moral menjadi tindakan moral yang efektif.

b. Keinginan (will), kemampuan untuk kuat dan bertahan melakukan apa yang seharusnya dilakukan berdasarkan pengetahuan dan perasaan moral.

c. Kebiasaan, adalah kemampuan untuk melakukan sesuatu secara konsisten dan berulang-ulang hingga telah terbiasa dan terasa lebih ringan untuk dilakukan secara terus-menerus.

\section{Faktor-faktor yang mempengaruhi pendidikan karakter}

Faktor-faktor tersebut, menurut Zubaedi faktor yang mempengaruhi keberhasilan atau kegagalan pendidikan karakter, yakni:

1. Faktor Insting (Naluri), Insting adalah sikap dan tabiat yang telah terbentuk sejak dilahirkan. 
2. Adat (Kebiasaan), Suatu perilaku yang sama dan diulang secara terus-menerus hingga menjadi terbiasa.

3. Keturunan (heredity), Sifat-sifat anak sebagian merupakan cerminan dari sikap dan sifat orangtuanya, baik secara rohani, maupun jasmani.

4. Lingkungan (milieu), Segala hal yang mengelilinginya mulai dari adat istiadat, pergaulan, keadaan sekolah, desa, kota, dsb akan memberikan pengaruh secara langsung atau tidak langsung pada karakter seseorang.

\section{Strategi pelaksanaan pendidikan karakter}

Masih dari Panduan Pelaksanaan Pendidikan Karakter Kemendiknas, agar pendidikan karakter dapat dilaksanakan secara optimal, pendidikan karakter dapat diimplementasikan melalui langkah-langkah sebagai berikut:

1. Sosialisasi ke stakeholders (komite sekolah, masyarakat, dan lembaga-lembaga lainnya)

2. Pengembangan dalam kegiatan sekolah

3. Menyelenggarakan kegiatan pembelajaran

4. Pengembangan Budaya Sekolah dan Pusat Kegiatan Belajar, melalui:
a. Kegiatan rutin
b. Kegiatan spontan
c. Keteladanan
d. Pengondisian

5. Kegiatan ekstra kurikuler

6. Menanamkannya melalui kegiatan keseharian di rumah dan di masyarakat

\section{Kurikulum Pendidikan Karakter}

Menurut Kemendiknas (2010: 11), kurikulum pendidikan karakter pada prinsipnya tidak dimasukkan sebagai pokok bahasan tetapi terintegrasi ke dalam mata pelajaran, pengembangan diri dan budaya sekolah. Menurut Agus Wibowo (2012:83), Prinsip pembelajaran yang digunakan dalam pengembangan kurikulum pendidikan budaya dan karakter bangsa mengusahakan agar peserta didik mengenal dan menerima nilai-nilai budaya dan karakter bangsa sebagai milik mereka dan bertanggung jawab atas keputusan yang diambilnya.

Akan tetapi pada awal tahun 2020 di Indonesia tertular wabah virus corona yang berdampak pada pendidikan di Indonesia. Dampak yang ditimbulkan yaitu ditiadakannya proses kegiatan belajar mengajar di sekolah dan diubah ke kegiatan belajar secara daring (dalam jaringan). Hal ini menyebabkan kurikulum pendidikan karakter ikut terhambat karena guru tidak bisa langsung menilai karakter siswa. Padahal dengan kurikulum pendidikan karakter guru harus mengintegrasikan nilai nilai pendidikan karakter pada setiap kegiatan belajar mengajar disetiap mata pelajaran. Walaupun pendidikan karakter tetap diterapkan selama pembelajaran daring tetapi tidak bias optimal karena guru tidak bias mengobservasi secara langsung.

\section{METODE PENELITIAN}

Penelitian ini menggunakan metode deskriptif kualitatif yang menggambarkan situasi atau objek dalam fakta yang sebenarnya secara sistematis. Pengumpulan data dilakukan dengan cara wawancara langsung kepada guru/kepala sekolah yang dituju. Lokasi penelitian adalah empat Sekolah Dasar yang berada di Kecamatan Taman diantaranya SDN 01 Pandean, SDN 02 Pandean, SDN Banjarejo, dan MIT Bakti Ibu. Wawancara dilakukan pada hari kerja antara senin-Jum'at pada minggu kedua Bulan Oktober.

\section{HASIL DAN PEMBAHASAN PENELITIAN}




\section{A. Program dan Pelaksanaan Pengembangan Kurikulum}

Pengembangan kurikulum dalam pendidikan karakter di SD Kecamatan Taman tiap tahun mengalami revisi. Sebab data yang diperoleh di beberapa sekolah dasar, masih banyak sekolah dasar yang belum bisa mengembangkan kurikulum sepenuhnya. Karena kurikulum yang sedang berlaku saat ini adalah kurikulum K13, namun ada beberapa materi yang harus dihilangkan sebab pandemi covid-19. Saat ini, kurikulum mengenai pendidikan karakter masih tetap ada di seluruh mata pelajaran namun lebih banyak di pelajaran PPKN. Karena didalam mata pelajaran PPKN banyak sekali pelajaran mengenai pendidikan karakter seperi disiplin, menjaga sikap yang baik, moral, perilaku dan lain-lain.Selain itu, guru juga memberikan kegiatan yang mendukung pendidikan karakter seperti kerja bakti (kegiatan ini bertujuan agar siswa dapat menerapkan kerja sama, saling gotong royong), belajar kelompok (di dalam belajar kelompok terdapat diskusi yang bisa menerapkan sikap saling menghargai pendapat teman), kepramukaan (menerapkan kedisiplinan, kekompakan, ketertiban) dan kegiatan ekstrakurikuler.

\section{B. Pelaksanaan}

Pelaksanaan kurikulum berdasar pengembangan kurikulum untuk meningkatkan pendidikan karakter di SD Kecamatan Taman adalah dengan menerapkan dan mengimplementasikan kegiatan sehari-hari dalam semua kegiatan sekolah. Beberapa kegiatan yang terdapat dalam kurikulum untuk pendidikan karakter di SD Kecamatan Taman adalah sebagai berikut :

1) Mengimplementasikan pendidikan karakter pada semua mata pelajaran.

2) Menumbuhkan budi pekerti pada peserta didik seperti doa bersama, ibadah bersama, dan peringatan hari-hari besar.

3) Melaksanakan upacara bendera setiap hari senin.

4) Mengucapkan salam saat bertemu maupun berpisah dengan orang lain

5) Menanamkan sikap disipilin, bertanggung jawab, dan saling membantu sesama

6) Memberikan kegiatan ekstrakurikuler di sekolah

7) Membangun budaya menjaga kebersihan di lingkungan sekitar

\section{Faktor Pendukung dan Penghambat Pengembangan Kurikulum}

Terdapat beberapa faktror yang mendukung dan menghambat pengembangan kurikulum dalam pendidikan karakter, yaitu :

1. Faktor pendukung

a. SDM (Sumber Daya Manusia)

Sumber daya manusia yang dimaksudkan disini adalah guru. Guru-guru memiliki peranan penting dalam peningkatan karakter siswa seperti memberikan contoh yang baik kepada peserta didik, berperilaku baik kepada semua orang, dan lain-lain.

b. Sarana dan prasarana sekolah

Sekolah menyiapkan sarana yang dipakai sebagai alat dan bahan untuk meningkatkan pendidikan karakter peserta didik dan prasarana untuk menunjang utama terselenggaranya pendidikan karakter peserta didik.

2. Faktor penghambat

a. Kepribadian Peserta Didik.

Kalau memang dari guru-guru sudah mengarahkan, memberikan contoh yang baik. Namun, hasilnya tidak maksimal, mungkin dari kepribadian peserta didik itu sendiri yang membuat karakter peserta didik kurang baik. 


\section{b. Lingkungan keluarga.}

Ketika di sekolah, guru mengajarkan karakter yang baik sebagai peserta didik. Namun jika di dalam keluarga, peserta didik diajarkan hal yang kurang baik maka peserta didik tidak akan sepenuhnya memiliki karakter yang baik. Sebab, lingkungan keluarga memiliki peranan yang penting dalam membangun karakter peserta didik.

c. Pandemi covid-19.

Dalam pandemi ini, banyak kegiatan yang kurang dilakukan dalam membangun pendidikan karakter untuk peserta didik sekolah dasar.

\section{KESIMPULAN}

1) Kurikulum adalah kumpulan rencana, tujuan, materi pembelajaran, dan bahkan cara mengajar yang digunakan sebagai pedoman oleh para pengajar demi tercapainya tujuan akhir pembelajaran.

2) Pengembangan kurikulum dalam meningkatkan pelaksanaan pendidikan karakter di SD Kecamatan Taman tiap tahun mengalami revisi atau perubahan. Sebab data yang diperoleh di beberapa sekolah dasar, masih banyak sekolah dasar yang belum bisa mengembangkan kurikulum sepenuhnya. Karena kurikulum yang sedang berlaku saat ini adalah kurikulum K13, namun ada beberapa materi yang harus dihilangkan sebab pandemi covid-19 karena materi tersebut yang tidak dapat dilaksanakan secara online. Saat ini, kurikulum mengenai pendidikan karakter masih tetap ada di seluruh mata pelajaran namun lebih banyak di pelajaran PPKN.

3) Kegiatan dalam kurikulum peningkatan pendidikan karakter adalah bahwa semua kegiatan di SD Kecamatan Taman dilaksanakan dengan selalu meningkatkan pendidikan karakter peserta didik.

4) Ada beberapa faktor pendukung dan faktor penghambat dalam meningkatkan pendidikan karakter peserta didik. Faktor pendukung adalah segala pengaruh baik secara langsung maupun tidak langsung yang berperan meningkatkan pendidikan karakter peserta didik yaitu SDM (Sumber Daya Manusia) serta sarana dan prasaran sekolah, sedangkan faktor penghambat adalah segala pengaruh dari luar sekolah sehingga peningkatan pendidikan karakter menjadi lambat dan kurang sesuai dengan pengembangan kurikulum di SD Kecamatan Taman yaitu kepribadian peserta didik, lingkungan keluarga, dan pandemi COVID-19.

5) Perbedaan pengembangan kurikulum pendidikan karakter sebelum dan setelah pandemi yaitu pada saat sebelum pandemi pengembangan pendidikan karakter dapat dilakukan secara langsung, guru dapat mengawasi dan menilai karakter peserta didik secara objektif. Sedangkan setelah pandemi guru hanya bisa menggunakan google form sebagai sarana untuk mengevaluasi perkembangan pendidikan karakter peserta didik, isi dari google form tersebut dapat berupa laporan diniyah seperti sholat lima waktu, kegiatan sehari hari, dan pemberian tugas praktik seperti video membantu orang tua dan lain sebagainya.

\section{DAFTAR PUSTAKA}

BAHRI, S. (2011). PENGEMBANGAN KURIKULUM DASAR DAN TUJUANNYA. JURNAL ILMIAH ISLAM FUTURA, 1534.

Dapur Ilmiah. (2014, Juni). dapurilmiah.blogspot.com. Retrieved 10 03, 2020, from dapurilmiah.blogspot.com: http://dapurilmiah.blogspot.com/2014/06/landasan-pengembangankurikulum.html

Fajri, K. N. (2019). Proses Pengembangan Kurikulum. Jurnal Keislaman dan Ilmu Pendidikan, 35-48.

Hamalik, O. (2012). Manajemen Pengembangan Kurikulum. Bandung: PT. Remaja Rosdakarya.

Harahap, A. P. (2019). Character Building Pendidikan Karakter. Jurnal Pendidikan dan Konseling, 1-11.

Haryati, S. (2017). Pendidikan Karakter dalam Kurikulum 2013. 
Judiani, S. (n.d.). Implementasi Pendidikan Karakter di Sekolah Dasar Melalui PenguatanPelaksanaan Kurikulum. 280-289.

Munajim, A., Barnawi, \& Fikriyah. (2020). Pengembangan Kurikulum Pembelajar di masa Darurat. Jurnl Riset Pedagogik, 285-291.

Mustikaningrum, G., Pramusinta, L., \& dll. (2020). Implementasi Pendidikan Karakter Terintegrasi Kurikulum dan Metode Pembelajaran Pada Masa Pandemi Covid 19. Jurnal Pendidikan Dasar Islam, 154-164.

Nurrohmah, S. (2018). PENGEMBANGAN KURIKULUM DALAM MENINGKATKAN PENDIDIKAN KARAKTER DI SEKOLAH DASAR. Peningkatan Kualitas Pendidikan Tinggi, Dasar, dan Menengah, 32-44.

Ramdhani, M. A. (2014). Lingkungan Pendidikan dalam Implementasi Pendidikan Karakter. Jrnal Pendidikan Universitas Garut, 27-37.

Rohendi, E. (n.d.). Pendidikan Karakter di Sekolah.

Wibowo, A. (2012). Pendidikan Karakter. Yogyakarta: Pustaka Belajar.

Widyawanti. (2015, september 21). Educational Technology. Retrieved 10 3, 2020, from Educational Technology web site: Educational Technology

Wuryandani, W., Maftuh, B., Sapriya, \& Budimansyah, D. (2014). Pendidikan Karakter Disiplin di Seklah Dasar. Cakrawala Pendidikan, 286-295. 